\title{
DELINEATING THE PLACE BRAND FACTORS INFLUENCING SOUTH AFRICA AS AN EMERGING BUSINESS TOURISM DESTINATION
}

\author{
Tafadzwa MATIZA* \\ Tourism Research in Economics, Environs and Society (TREES) Unit, North West University, \\ Faculty of Economic and Management Sciences, School of Tourism, Building E3, \\ Office 23oB, Hofman Street, Potchefstroom, South Africa, 2531, e-mail: matizata@hotmail.com
}

\begin{abstract}
Citation: Matiza, T. (2020). DELINEATING THE PLACE BRAND FACTORS INFLUENCING SOUTH AFRICA AS AN EMERGING BUSINESS TOURISM DESTINATION. GeoJournal of Tourism and Geosites, 28(1), 114-126. https://doi.org/10.30892/gtg.28109-456
\end{abstract}

\begin{abstract}
The proliferation of place brands within the global tourism market has resulted in the need for emerging business tourism markets such as South Africa to better understand their potential influence on tourists' decision-making. The aim of the study was to delineate the place brand factors influencing business tourism to South Africa and explore the nexus between South Africa's place brand and business tourism. Quantitative data was generated from a convenient sample of $n=233$ inbound tourists to South Africa. Exploratory Factor Analysis and Multiple Regression Analysis were employed, utilising the Statistical Package for Social Sciences (SPSS 25.0) to analyse the data. The study found evidence of a statistically significant relationships between South Africa's Socio-cultural and Tourism place brand aspects, and business tourism to the country. These findings suggest that South Africa's place brand is an inferential heuristic cue that may have a halo effect on the predilections of business-oriented tourists.
\end{abstract}

Key words: Business tourism, heuristic cues in tourism, place brands, South Africa, tourist behaviour

\section{INTRODUCTION}

African tourism destinations are synonymous with leisure and nature-oriented tourism activities; as a result, business tourism represents an emerging and niche form of tourism for a significant proportion of African countries (Hoogendoorn \& Rogerson, 2016; Signé, 2018; Tichaawa, 2017). Generally, business tourists represent a particularly affluent and non-seasonal consumer segment within the tourist market, with the average business tourist spending up to three hundred percent more than the typical leisure tourist (Kumar et al., 2018; Marais et al., 2017; Signé, 2018). Not surprisingly, the economic multiplier effect of business tourism has been linked to infrastructure development, employment creation, and integrated tourism value chains

\footnotetext{
* Corresponding author
} 
with other more traditional forms of tourism (Chiang et al., 2012; Kumar et al., 2018; Kumar \& Hussain, 2014; Marias et al., 2017). Globally, business-related travel and tourism accounted for $22.5 \%$ (US\$1 230.6bn) of the global travel and tourism gross domestic product (GDP) in 2017 (World Travel and Tourism Council - WTTC, 2018a).

In the case of South Africa, business travel contributed an estimated US\$7.4bn to the South African economy (WTTC, 2018b). With the WTTC (2018a) projecting global business travel and tourism spend at an estimated US $\$ 1756.1$ bn by 2028 , African tourism destinations such as South Africa are poised to reap the economic benefits of the emerging tourism market segment if they are 'positioned' strategically within the global tourism market. The effective positioning of places as business tourism destinations is a critical, but under-researched area of tourism (Rogerson, 2015; Tichaawa, 2017) underpinned by the need for a better understanding of business tourist behaviour as well as the potential influence of place brands on the behaviour of business tourists within emerging business tourism destinations.

Understanding tourist behaviour is imperative for the competitiveness of tourism destinations and is the cornerstone of contemporary destination marketing research (Khairi et al., 2019). To this end, the notion that tourist behaviour is influenced by destination images is well established within the tourism discourse. While there is a plethora of destination image research investigating the influence of destination images on tourist behaviour (Apostolopoulou \& Papadimitriou, 2015; Kim et al., 2009; MartinezSantana et al., 2017; Pike, 2016), academic inquiry into the effect of the generic place brand on tourist decision-making is still very limited, more-so within the African context. Moreover, research into the heuristic value of place brands in providing information symmetry for the travel decisions of business tourists is also limited compared to that of leisure tourists. This despite empirical evidence suggesting that information symmetry is significant to the decision-making process of business tourists and represents a critical success factor for business tourism (Chiang et al., 2012; Marais et al., 2017).

Relatedly, Africa suffers from a significant image deficit, particularly fuelled by negative stereotypical perceptions (Hemmonsbey \& Knott, 2016; Schorr, 2011; Signé, 2018). As a result, the marketing axiom of perceived reality and its influence on consumer decision-making (Pike, 2016), is valid in suggesting that research into the effect of African place brands, on tourist behaviour such as South Africa's place brand, is imperative for the growth and development of business tourism destinations on the continent. Moreover, within the context of emerging African business tourism destinations, there is a discernible dearth of research into business tourism in general and, more pertinently the decision-making process of business tourists, when considering visiting African destinations (Donaldson, 2013; Marais et al., 2017; Rogerson, 2015; Tichaawa, 2017). Therefore, the aim of the study was to examine the place brand - business tourism nexus within the South African context, by delineating the place brand factors influencing tourist perceptions of South Africa as a business tourism destination. Thus, this paper makes three significant contributions to the business tourism discourse.

Firstly, the present paper contributes to the tourism literature by providing new insights into, and a better understanding of the potential effect of place brands on business tourist decision-making within the African context. Secondly, this paper expands the characterisation of business tourism by exploring the viability of previou sly excluded business-oriented tourism activities (academic, short-term employment, shopping and other corporate business activities) and providing empirical evidence to support the notion within the wider tourism literature. Thirdly, and more pertinently, the current paper provides tourism marketing practitioners in South Africa with critical 
insights into tourist perceptions of South Africa as a business tourism destination by examining the South African place brand-business tourism nexus.

\section{LITERATURE REVIEW}

\section{Business tourism}

Conventionally, business-oriented tourism is associated with activities such as meetings, incentives, conferences and exhibitions (MICE) (Donaldson, 2013; Marais et al., 2017), and is often defined within that context as involving, "... the traveling of people for the purpose of work and encompasses independent business trips as well as travelling for purposes of meetings, incentives, conferences, and exhibitions (MICE) tourism," (Tichaawa, 2017: p. 181). This characterisation of business tourism holds true in the case of South Africa which concurs with the conventional characterisation of business tourism (National Tourism Sector Strategy, 2012). To this end, the most recent tourism statistics report that business tourism accounted for just $12 \%$ of the 10.04 million and 8\% of the 10.3 million tourists that visited South Africa in 2016 and 2017, respectively (Statistics South Africa, 2017) supporting the emerging status of business tourism within the South African context. Importantly, these figures exclude tourists who visited South Africa to shop for business purposes (cross-border traders), shortterm workers and/or academic activities. Within the African context, there are contestations regarding the characterisation of business tourism, particularly since some of the literature (Rogerson, 2015, 2018, Tichaawa, 2017) argues that business tourism extends to other socio-economic aspects, such as retailing (cross-border trading trips), short-term employment, and academic activities. The extension of the conceptualisation of business tourism activities, particularly within the African context, expands the business tourism market segment, and thus incorporates a wider crosssection of tourists, thereby necessitating further academic inquiry into the behaviour of business tourists. With this in mind, this paper presents a unique perspective by conceptualising and examining business tourism beyond the conventional MICE activities by incorporating other business-related activities to include: academic activities (Bento, 2014; Roderiguez et al., 2013); short-term employment (Chikanda \& Tawodzera, 2017) and shopping (Rogerson, 2018) as well as other corporate business activities such as product delivery, sourcing or launching, and sales trips (Tichaawa, 2017).

\section{The role of place brands in tourism and tourist behaviour}

The place brand is characterised by Zenker and Braun (2010:5) as,

“...a network of associations in the consumers' mind based on the visual, verbal, and behavioural expression of a place, which is embodied through the aims, communication, values, and the general culture of the place's stakeholders and the overall place design,"

From this perspective, the place brand represents two critical aspects - image (an existing perception or reputation) and/or a value promise (a unique and relevant positioning) in the minds of consumers (Belloso, 2010; Park \& Lee, 2017). This suggests that place brands are cognitive in nature and as inferential heuristic cues, may have an overall influence on the evaluation of tourism destinations, thus giving credence to the notion of the importance of place brands in informing the subjective preferences of tourists in their decision-making (Brijs et al., 2011; Martin-Santana et al., 2017; Wang et al., 2012).

Of particular interest within the place brands-tourism nexus is the halo effect (Han, 1989), which hypothesises that consumers use the place brand as a heuristic cue for information symmetry - thereby influencing any subsequent evaluations of a country's particular products such as tourism offerings (Kang \& Yang, 2010; Han, 1989; 
Matiza \& Oni, 2014; Stepchenkova et al., 2018). Based on this premise, it then follows that place brands are inextricably linked to the manner in which consumers process information associated with the place (competitive and comparative advantages), their affective behaviour, as well as their conative behaviour (Apostolopoulou \& Papadimitriou, 2015; Souiden, et al., 2017). Generally, the literature (Brijs et al., 2011; Elliot \& Papadopoulos, 2016; Kiryluk \& Glinska, 2015; Wang et al., 2012) observes a relationship between the place brand and the behaviour of various consumer groups, including tourists. For instance, Wang et al., (2012) provide empirical evidence that in the absence of product information, Chinese consumers utilised the source country image (place brand) as a heuristic cue to infer product quality evaluation and inform their behaviour when evaluating American, German, Japanese and Korean products. While, specifically within the tourism context, prior studies (Park \& Lee, 2017; Souiden et al., 2017; Qu et al., 2011; Zeugner-Roth \& Zabkar, 2015) have supported the notion that place brands influence and elicit predictable tourist behaviour.

\section{Measuring place brands}

Globalisation and the resultant increase in competitive forces, have buoyed the proliferation of contemporary brand theory beyond conventional products and services into new fields of study and unconventional "products" - such as the branding of places within the tourism context (Hemmonsbey \& Knott, 2016; McCreary et al., 2019).

However, the subjective and complex nature of place brands, compounded by the intangibility of tourism product offerings, as well as the diversity of tourism destinations, has presented researchers with a myriad of challenges in measuring place brands and their associated dimensions as well as the influence of place brands on tourists (Agapito et al., 2013; Knott et al., 2013; Marais et al., 2017; Martinez \& Alverez, 2010; Slabbert \& Martin, 2017). As a result, while some individual place brand-related studies have quantitatively measured place brands, there seems to be no consensus within the literature regarding the most suitable measurement instrument for place brands (McCreary et al., 2019; Souiden et al., 2017).

Nation branding theory does however, attempt to standardise the measurement of place brands within various fields. The theory posits that places, akin to corporate entities, are susceptible to both positive and negative perceptions that ultimately influence the behaviour of their external stakeholders - who include tourists (Anholt, 2002, 2007; Dinnie, 2008; Njeru, 2010). According to Anholt (2002, 2007) and Žugić and Konatar (2018), consumers interact with a country (place) through one or multiple dimensions, and make their product evaluations based on:

- Governance - the perceptions of the government and its actions

- Cultural and heritage - the history, values and achievements associated with the place

- Tourism - the attractiveness of the place from a tourism perspective

- People (human capital) - the pervasive views/opinions of the citizens of the place

- Investment and immigration - the perceptions of the socio-economic conditions of the place and the willingness to live and work there and/or

- Exports - the perceptions and/or stereotypes of the products associated with the place.

To this end, various studies (Brijs et al., 2011; Souiden et al., 2017; Wang et al., 2012; Žugić \& Kantar, 2018) have measured place brands as a mental representation of a country based on: socio-economic; technological; cultural; people; historical (cultural heritage); economic development; and/or political variables. The present paper, after excluding exports as a factor, adopted five of the six conventional nation brand hexagon dimensions as measures within the tourism context as follows: Cultural heritage (Kemp et al., 2012); Governance (Steyn \& van Vuuren, 2016); Tourism (Reitsamer \& 
Brunner-Sperdin, 2017); Immigration (Cook, 2010) and People (Das \& Mukherjee, 2016). Given the dynamic and competitive nature of the contemporary global tourism market, the influence of two novel factors, Marketing (Han \& Hyun, 2014) and Negative Events (Avraham, 2018) was also examined.

The following hypotheses were thus formulated for the study:

$H_{1}$ : $\quad$ South Africa's cultural heritage as a place brand factor influences business tourism to South Africa.

$\mathrm{H}_{2}$ : $\quad$ South Africa's governance as a place brand factor influences business tourism to South Africa.

$\mathrm{H}_{3}$ : $\quad$ South Africa's marketing as a place brand factor influences business tourism to South Africa.

$\mathrm{H}_{4}$ : $\quad$ South Africa's tourism as a place brand factor influences business tourism to South Africa.

$H_{5}$ : $\quad$ South Africa's negative events as a place brand factor influences business tourism to South Africa.

$H_{6}$ : $\quad$ South Africa's immigration as a place brand factor influences business tourism to South Africa.

$H_{7}$ : $\quad$ South Africa's people as a place brand factor influences business tourism to South Africa.

\section{RESEARCH METHOD}

The aim of the present study was to examine the place brand-business tourism nexus within the South African context. The positivist paradigm was most suitable for the purpose of the hypothesis testing. A quantitative cross-sectional deductive study was conducted to generate the data required from a sample of inbound tourists to South Africa. Due to the key informant nature of the target population, non-probabilistic convenient sampling was employed. An effective sample of $n=233$ foreign tourists was drawn from visitors visiting one of South Africa's most iconic tourist attractions, Table Mountain in Cape Town, between the $6^{\text {th }}$ and $9^{\text {th }}$ of November 2018.

Data was generated by way of a self-administered survey disseminated to tourists at the Table Mountain Aerial Cableway station by a team of four trained fieldworkers. The novel survey instrument consisted of four sections that solicited sociodemographic, general perception, influential factors of South Africa's place brand and travel motives, respectively. The South African place brand factors were measured by observed variables drawn from the literature as previously discussed.

An ordinal 5-point Likert type scale was developed to record tourist responses to 44 statements related to South Africa's place brand factors. Responses on the scale ranged from (1) Not at all influential to (5) Extremely influential. Data on the Business tourism factor was also generated from a literature-based (Gowreesunkar \& Sotiriadis, 2015) ordinal 5-point Likert type scale for five statements on the business travel motives of tourists relating to South Africa. Responses on the travel motives scale ranged from (1) Strongly disagree to (5) Strongly agree. The survey responses were collated on a Microsoft Excel sheet and then exported to Statistical Package for Social Sciences (SPSS 25.0) for analyses. The Kaiser-Meyer-Olkin (KMO) measure of sampling adequacy (at $\geq .50$ ) and Bartlett's test of sphericity with a null significance value were employed to determine the factorability of the data (Field, 2011). In order to establish the factor model for the South African place brand factors influencing tourism to South Africa, Principal Components Analysis (PCA) was employed to generate the values underlying the place brand factors influencing business tourism to South Africa, with 
factors indicating an Eigenvalue of $\mathrm{EV}>1$ being retained (Hair et al., 2006). An exploratory factory analysis (EFA) Oblimin with Kaiser Normalisation then extracted and clustered the correlated items into discernible place brand factors (Norris \& Lecavalier, 2010), at factor loading coefficient of $\geq .40$, in line with the recommendations of Hair et al. (2006) for samples of at least $n \geq 200$. Construct reliability (inter-item consistency) was verified using the Cronbach's alpha ( $\alpha$ ) test at a lower limit of .60 , which is regarded acceptable for exploratory studies in order to accommodate scales with fewer items (Field, 2011; Hair et al., 2006; Nunally \& Berstein, 1994). Descriptive statistics were also calculated.

\section{ANALYSES AND RESULTS \\ Tourist profile}

Table 1 summarises the profile of the tourists surveyed

Table 1. Tourist profile

\begin{tabular}{l|rc}
\hline \multicolumn{1}{c}{ Segment } & Percentage (\%) \\
\hline \multirow{2}{*}{ Gender } & Male & 55.1 \\
& Female & 44.9 \\
\hline \multirow{4}{*}{ Age } & $<19$ & 3.1 \\
& $20-30$ & 30.5 \\
& $31-40$ & 26.5 \\
& $41-50$ & 10.0 \\
Education & $51-60$ & 11.3 \\
& $>61$ & 7 \\
& Did not mention & 12.6 \\
\hline \multirow{4}{*}{ Employment status } & Non-formal & 1.5 \\
& High school & 17.0 \\
& Bachelor's degree & 39.4 \\
& Post graduate degree & 22.6 \\
& Professional qualification & 19.3 \\
\hline \multirow{4}{*}{ Country of residence } & Student & 9.0 \\
& Unemployed & 2.4 \\
& Employed (Private sector) & 54.9 \\
& Employed (Public sector) & 24.5 \\
& Retired & 9.2 \\
\hline \multirow{3}{*}{ Number of visits } & United Kingdom & 19.4 \\
& Netherlands & 7.1 \\
& United States of America & 11.6 \\
& Germany & 15.4 \\
& Other & 46.6 \\
\hline & First visit & 75.0 \\
& More than 1 visit & 24.5 \\
& Did not mention & 0.5 \\
\hline
\end{tabular}

As shown in Table 1, a slight majority of the tourists surveyed were male (55.1\%), while the majority (cumulative 57\%) were aged between 20 and 40 years old. Notably, $18.3 \%$ of the survey population were aged $>51$ years old. Most of the respondents possessed a degree (62\%), either a bachelor's $(39.4 \%)$ or post-graduate $(22.6 \%)$ degree, and were employed $(79.4 \%)$ at the time of the survey. Interestingly, $9.2 \%$ of the respondents indicated that they were retired. The four main country of origin/residence 
segments were the UK (19.4\%), Germany (15.4\%) the USA (11.6\%), and the Netherlands (7.1\%), of which the majority of all the foreign visitors surveyed (75.0\%), indicated that they were visiting South Africa for the first time.

Results for the PCA, EFA and Cronbach's alpha for the South African place brand factors and Business Tourism

The PCA and EFA were employed to establish the factor models, and then extract and cluster the correlated items into discernible constructs for the place brand factors influencing tourism to South Africa, as well as the Business Tourism factors, respectively. The KMO (.854) and Bartlett's test of sphericity $\left(\chi^{2}(946)=4919.853, p<\right.$ .001), supported the factorability of the survey data. Table 2 is a summary of the PCA, EFA, reliability test and the descriptive statistics.

Table 2. Summary of results for the PCA, EFA and Cronbach's alpha of the place brand factors influencing tourism to South Africa

\begin{tabular}{|c|c|c|c|c|c|c|c|c|}
\hline \multirow[t]{2}{*}{ Factor } & \multirow[t]{2}{*}{ *Items } & \multicolumn{2}{|c|}{$\begin{array}{c}\text { Factor } \\
\text { Loading } \\
(>0.40)\end{array}$} & \multirow[t]{2}{*}{$\mathbf{E V}$} & \multirow[t]{2}{*}{$\begin{array}{l}\text { Var } \\
(\%)\end{array}$} & \multirow[t]{2}{*}{$\begin{array}{c}\text { Alpha } \\
\text { (a) }\end{array}$} & \multicolumn{2}{|c|}{$\begin{array}{l}\text { Descriptive } \\
\text { statistics }\end{array}$} \\
\hline & & Min & $\operatorname{Max}$ & & & & $\begin{array}{c}\text { Mean } \\
(\bar{x})\end{array}$ & $\begin{array}{c}\text { Std } \\
\operatorname{Dev}(\sigma)\end{array}$ \\
\hline $\begin{array}{l}\text { Socio-Cultural } \\
\quad \text { (SCU) }\end{array}$ & $\begin{array}{l}\text { IMM3, IMM4, } \\
\text { IMM5, CLH1, } \\
\text { CLH2, CLH3, } \\
\text { CLH4, CLH5, } \\
\text { PEO1, PEO2, } \\
\text { PEO3, PEO4 }\end{array}$ & .478 & .789 & 13.01 & 29.58 & .918 & 3.42 & .756 \\
\hline $\begin{array}{l}\text { Governance } \\
\text { (GOV) }\end{array}$ & $\begin{array}{l}\text { GOV1, GOV2, } \\
\text { GOV4, GOV } 5 \\
\text { GOV6 }\end{array}$ & .669 & .786 & 3.17 & 7.20 & .860 & 3.12 & .977 \\
\hline $\begin{array}{l}\text { Marketing } \\
\text { (MKT) }\end{array}$ & $\begin{array}{l}\text { PEO7, MKT3, } \\
\text { MKT4, MKT5, } \\
\text { MKT6, MKT7 }\end{array}$ & .499 & .806 & 2.74 & 6.23 & .885 & 3.62 & .816 \\
\hline $\begin{array}{l}\text { Tourism } \\
\text { (TOR) }\end{array}$ & $\begin{array}{c}\text { TOR3, TOR5, } \\
\text { TOR6, TOR8, } \\
\text { GOV } 3\end{array}$ & .519 & .693 & 2.35 & $5 \cdot 35$ & .659 & 2.97 & .950 \\
\hline $\begin{array}{c}\text { Negative } \\
\text { Events (NEV) }\end{array}$ & $\begin{array}{l}\text { NEV1, NEV2, } \\
\text { NEV3, NEV4, } \\
\text { NEV5, NEV6 }\end{array}$ & .457 & .751 & 1.92 & $4 \cdot 36$ & .864 & 3.18 & .883 \\
\hline $\begin{array}{c}\text { Competitive } \\
\text { Advantages } \\
(\mathrm{CAV})\end{array}$ & $\begin{array}{c}\text { TOR2, TOR4, } \\
\text { TOR7, IMM1, } \\
\text { IMM2 }\end{array}$ & .507 & .659 & 1.47 & $3 \cdot 34$ & .682 & 3.86 & .696 \\
\hline
\end{tabular}

Key: Culture and Heritage $=$ CLH; Governance $=$ GOV; Marketing $=$ MKT; Tourism $=$ TOR; Negative Events $=$ NEV; People $=$ PEO; Immigration $=$ IMM

Table 2 summarises the six place brand factors influencing tourist decision-making within the South African context. As a result of the PCA $(\mathrm{EV}>1)$ and EFA (Oblimin with Kaiser Normalisation at the cut-off of $>.40$ ), the identified place brand factors were: Governance (5 items; EV = 3.17; $\alpha=.860$ ); Marketing ( 6 items; EV = 2.74; $\alpha=.885$ ); Tourism (5 items; EV = 2.35; $\alpha=.659$ ) and; Negative Events ( 6 items; EV = 1.92; $\alpha=$ .864). Notably, some immigration, cultural heritage and people items loaded onto a new factor which was relabelled Socio-Cultural (12 items; EV = 13.01; $\alpha=.918$ ). While a 
completely new factor labelled Competitive Advantages ( 5 items; $\mathrm{EV}=1.47 ; \alpha=.682$ ) also loaded as a place brand factor potentially influencing business tourism to South Africa. Factor loading coefficients for all the place brand factors ranged between .478 and .806 , explaining a cumulative $56.06 \%$ of the variance in the data. All subscales were deemed reliable, ranging between $\alpha=.659$ and $\alpha=.918$. Table 3 presents the EFA, PCA and Cronbach's alpha test results of the antecedents of Business Tourism to South Africa.

Table 3. Results of the EFA, PCA and Cronbach's alpha tests

for the antecedent factors of Business Tourism in South Africa

\begin{tabular}{l|c}
\hline Items & $\begin{array}{c}\text { Factor Loading } \\
(>.40)\end{array}$ \\
\hline Allows access to academic activities/ opportunities (teacher/student & .724 \\
exchange, studying for a period <1-year, research) & .818 \\
Hosts major international congresses, conventions, exhibitions and trade fairs & .685 \\
Is a shopping paradise & .809 \\
Is attractive/offers me opportunities for short-term migration for & \\
employment purposes (working holiday) & .797 \\
Is a good destination for corporate business trips (product & $\mathbf{2 . 1 2 7}$ \\
delivery/sourcing/launching, sales trips) & $\mathbf{1 0 . 1 3}$ \\
\hline Eigenvalue (EV) & $\mathbf{. 8 8 0}$ \\
Variance explained (\%) & $\mathbf{3 . 0 5}$ \\
Mronbach's alpha (a) & $\mathbf{. 9 1 7}$ \\
\hline
\end{tabular}

${ }^{*}$ KMO = .854; Bartlett's test of Sphericity $\left(\chi^{2}(210)=2979.398, p<0.001\right)$

Table 3 validates that South Africa is perceived as a Business Tourism destination. As a result of the PCA $(\mathrm{EV}>1)$ and EFA (Oblimin with Kaiser Normalisation at $>.40$ ), Business Tourism emerged as a valid tourism typology in South Africa and was constituted of 5 items $(\mathrm{EV}=2.13$; explaining variance of $10.13 \% ; \alpha=.880)$. The factor loading coefficients for Business Tourism ranged between .685 and .818 . The Business Tourism subscale was also deemed to be reliable $(\alpha>.70)$.

After the PCA and EFA analyses, the hypotheses were (re)formulated as follows:

$H_{1}$ : South Africa's socio-cultural profile as a place brand factor influences business tourism to South Africa.

$\mathrm{H}_{2}$ : $\quad$ South Africa's governance as a place brand factor influences business tourism to South Africa.

$\mathrm{H}_{3}$ : $\quad$ South Africa's marketing as a place brand factor influences business tourism to South Africa.

$\mathrm{H}_{4}$ : $\quad$ South Africa's tourism as a place brand factor influences business tourism to South Africa.

$H_{5}$ : South Africa's negative events as a place brand factor influences business tourism to South Africa.

$H_{6}$ : South Africa's competitive advantages as a place brand factor influences business tourism to South Africa.

\section{Tourism}

Correlation analysis of South Africa's place brand factors and Business

The results listed in Table 4 show the correlations between South Africa's place brand factors and Business tourism. 
Table 4. Correlation matrix of South Africa's place brand factors and Business Tourism to South Africa

\begin{tabular}{l|lllllll}
\hline Variables & BTR & SCU & GOV & MKT & TOR & NEV & CAV \\
\hline Business Tourism (BTR) & $\mathbf{1 . 0 0 0}$ & & & & & & \\
Socio-Cultural (SCU) & $.225^{* * *}$ & $\mathbf{1 . 0 0 0}$ & & & & & \\
Governance (GOV) & .111 & $.420^{* *}$ & $\mathbf{1 . 0 0 0}$ & & & & \\
Marketing (MKT) & .015 & $.521^{* *}$ & $.338^{* * *}$ & $\mathbf{1 . 0 0 0}$ & & & \\
Tourism (TOR) & $.355^{* *}$ & $.328^{* *}$ & $.387^{* *}$ & $.274^{* * *}$ & $\mathbf{1 . 0 0 0}$ & & \\
Negative Events (NEV) & $.146^{*}$ & $.554^{* *}$ & $.411^{* *}$ & $.542^{* *}$ & $.390^{* *}$ & $\mathbf{1 . 0 0}$ & \\
Competitive Advantages (CAV) & .014 & $.437^{* *}$ & $.328^{* *}$ & $.493^{* *}$ & $.345^{* *}$ & $.38^{* *}$ & $\mathbf{1 . 0 0 0}$ \\
\hline
\end{tabular}

**Correlation is significant at the o.oo1 level (2-tailed)

* Correlation is significant at the o.o5 level (2-tailed)

Table 5. Summary of the results of the Multiple Regression Analysis: Business Tourism

\begin{tabular}{lccc|cc|cc}
\hline \multicolumn{2}{l}{ Dependent variable: Business Tourism } & & \multicolumn{2}{|c|}{$\begin{array}{c}\text { Collinearity } \\
\text { statistics }\end{array}$} & & \\
\hline $\begin{array}{l}\text { Independent variables } \\
\text { (R²=.182) }\end{array}$ & $\boldsymbol{\beta}$ & $\begin{array}{c}\mathbf{t}- \\
\text { value }\end{array}$ & $\begin{array}{c}\text { Sig. } \\
\text { (p) }\end{array}$ & Tol. & VIF & Hyp. & Outcome \\
\hline Socio-Cultural (SCU) & .254 & 3.011 & $.003^{* *}$ & .573 & 1.744 & $\mathrm{H}_{1}$ & Accepted \\
Governance (GOV) & -.050 & -.668 & .505 & .723 & 1.383 & $\mathrm{H}_{2}$ & Rejected \\
Marketing (MKT) & -.133 & -1.581 & .115 & .527 & 1.750 & $\mathrm{H}_{3}$ & Rejected \\
Tourism (TOR) & .377 & 5.140 & $.000^{*}$ & .755 & 1.324 & $\mathrm{H}_{4}$ & Accepted \\
Negative Events NEV) & .003 & .039 & .969 & .559 & 1.787 & $\mathrm{H}_{5}$ & Rejected \\
Competitive Advantages (CAV) & -.146 & -1.881 & .061 & .676 & 1.478 & $\mathrm{H}_{6}$ & Rejected \\
\hline * & & & & & & &
\end{tabular}

${ }^{*} \mathbf{p}<\mathbf{0 . 0 0 1}{ }^{* *} \mathbf{p}<\mathbf{0 . 0 5}$

As is evident in Table 4, Business Tourism was significantly correlated with the Tourism ( $r=.355, \mathrm{p}<.001)$; Socio-cultural $(r=.225, \mathrm{p}<.001)$ and; Negative events $(r=$ $.146, \mathrm{p}<.05)$ place brand factors, respectively.

There were however, non-significant correlations of .111(p = n.s);.015 (p = n.s), and; .014 ( $\mathrm{p}=\mathrm{n} . \mathrm{s})$, between Business Tourism and the Governance, Marketing, and Competitive Advantages place brand factors respectively.

Multiple regression analysis of the South African place brand factors

\section{influencing Business Tourism to South Africa}

MRA was then employed to test if South Africa's place brand was of a statistically significant influence to Business Tourism to South Africa. Table 5 summarises the results of the Multiple Regression Analysis.

The results of the regression analysis in Table 5 indicated that two South African place brand factors influenced Business Tourism, explaining $18.2 \%$ of the variance $\left(\mathrm{R}^{2}=.182, \mathrm{~F}(6,201)=7.46, \mathrm{p}<.001\right)$. The place brand factors, Tourism $(\beta=.38, \mathrm{p}=.000)$ and Socio-cultural $(\beta=.25, \mathrm{p}=.003)$ significantly influenced Business Tourism to South Africa. Additionally, the t-values for each statistically significant South African place brand factor reported critical t-values of between 1.96 and 3.09 at $\mathrm{p}<.05$ (Socio-cultural) and exceeded the 3.09 at $\mathrm{p}<.001$ (Tourism), thus hypothesis $\mathrm{H}_{1}$ and $\mathrm{H}_{4}$ were accepted.

The place brand factors Governance, Marketing, Negative Events and Competitive Advantages reported non-statistically significant ( $\mathrm{p}>.05)$ relationships with Business Tourism to South Africa. Thus, hypotheses $\mathrm{H}_{2}, \mathrm{H}_{3}, \mathrm{H}_{5}$, and $\mathrm{H}_{6}$ were rejected.

\section{DISCUSSION}

The empirical evidence suggests a correlation and the existence of a statistically significant effect between of South Africa's place brand and business tourism to the 
country. As it emerged, the socio-cultural and tourism factors of South Africa's place brand influence tourists' perceptions and may have a discernibly predictive effect on business tourism to South Africa. Theoretically, this finding is fundamentally supported by nation branding theory, which advances the notion that consumers may interact with, and are susceptible to the influence of one or more place brand factor(s) in their decisionmaking process in evaluating products from specific countries (Anholt, 2002).

The influence South Africa's place brand on business tourism to the country is supported by the literature (Brijs et al., 2011; Chiang et al., 2012; Marais et al., 2017; Martin-Santana et al., 2017; Wang et al., 2012) which propagates to some extent, the significance of place brands as inferential heuristic cues that have an effect on the predilections of tourists. Relatedly, evidence of a place brand-business tourism nexus validates and extends the notion of the halo effect of place brands within an African business tourism context supporting the views of some authors, such as (Apostolopoulou \& Papadimitriou, 2015; Han, 1989; Matiza \& Oni, 2014; Park \& Lee, 2017; Stepchenkova et al., 2018; Souiden et al., 2017) - that while place brands influence the decision-making processes of tourists, they may also be predictive in nature. This implies that despite place brands being cognitive in nature, they may also influence how tourists evaluate tourism destinations (affective behaviour) and ultimately influence the intention to (re)visit (conative behaviour) of tourists. To be more specific, prior studies have to some extent explored the nexus between some socio-cultural and tourism aspects of places and business tourism. For instance, the reasonability of a relationship between South Africa's socio-cultural aspects and business tourism to the country through the influence of friendly trade policies, as well as the entrepreneurial nature and innovativeness of South Africans, is supported by Gisore and Ogutu (2015), as well as Signé (2018).

These researchers found evidence that expansionist and friendly trade policies aimed at exploiting mineral resources in Africa attract more business-oriented travellers, thus providing growth opportunities for business tourism for African destinations (Gisore \& Ogutu, 2015; Signé, 2018). Relatedly, socio-cultural aspects such as the quality of life, public resources (health and education) and the availability of efficient basic service utilities (water, electricity) in South Africa may be associated with the demand for business tourism. This notion is supported by Bento (2014) and Roderiguez et al. (2013), who found that in the case of international student mobility within the European Union, both economic (standard of living) and non-economic (quality of public resources) factors influenced academic tourism demand for certain destinations.

The findings of the present study also indicate the probable influence tourism factors on business tourism to South Africa. For instance, the proximity of South Africa to the country of origin of the business tourist, as well as the proximity of South Africa to other African tourist destination countries may have an influence on business tourism to the country. To this end, Ho and McKercher (2014) found evidence supporting this notion, observing that in 2014 the proximity of Hong Kong to 14 of its major source markets exerted a significant impact on inbound tourist arrivals with statistically significant differences being observed between long-haul and short-haul business travellers in the consideration of Hong Kong for business travel. Relatedly, tourism aspects such as the relations between South Africa and the home country of the business tourist may have an influence on the tourist's perceptions and their intention to (re)visit South Africa for business. Alvarez and Campo (2019) support the reasonability of this notion, finding that the ethnocentric tendencies and general animosity of American tourists towards a tourism destination country significantly influenced their perceptions and conative behaviour of toward the tourism destination. 
This study is also novel in that it models the influence of place brands on a 'broader' business tourism construct. As it emerged, MICE, as well as short-term employment, shopping, academic, and other corporate business activities such as product launches are antecedents to business tourism to South Africa. The empirical evidence from the case of South Africa, thus gives credence to the contentions by Rogerson (2018) and Tichaawa (2017), that the conceptualisation of business tourism within the African context goes beyond what they term the formal 'Northern' definition of business tourism. This implies that business tourism arrivals, as well as the direct and indirect socioeconomic impacts of business tourism may be more significant than reported by national tourism statistics such as those provided by Statistics South Africa.

\section{CONCLUSION}

Based on the findings of the present study, the following conclusions may be made. First, South Africa's place brand may be significant to the growth and development of South Africa as an emerging business tourism destination. This implies that South African destination marketers must be cognisant of how South Africa is generally perceived as a country and seek to proactively manage these perceptions as part of a multi-stakeholder approach to marketing the country as a business tourism destination. Second, with particular reference to the assertions of Schorr (2011) and Signé, (2018) relating to the pre-existing deleterious perceptions of Africa, it is reasonable to hypothesise that positive place brand factors may be harnessed by destination marketing practitioners when marketing their countries as business tourism destinations to counteract the effects of the negative stereotypes associated with Africa.

Implying that place brands may be utilised as strategic assets to effectively manage or influence business tourist perceptions and better position African countries as business tourism destinations. Third, there is also a valid premise for the expansion of the definition of business tourism within the African context based on the validity of the additional business-related activities beyond the traditional MICE.

Therefore, this study contributes to the ongoing debate in tourism literature on the role and characterisation of short-term academic, cross-border trading and shortterm employment activities in business tourism.

The findings of this study contribute to the extent of the literature within the general tourism discourse, by extending place branding theory to an emerging African business tourism destination, while providing an African perspective to tourist behaviour within the burgeoning business tourism discourse. However, it is important to acknowledge that there is need for much broader research into the influence of place brands on business tourism, the more so given that the scope of this study is limited to just a cross-section of inbound tourists to South Africa. A broader study that encompasses respondents from major tourism source markets for South Africa would further validate the measuring instrument, as well as the findings of the present study. Such a study is all the more important as the perspectives of tourists who have visited, have considered visiting but had decided not to visit, and those who would consider visiting South Africa in the future for business would also provide more critical insights into the South Africa's place brand-business tourist behaviour nexus.

Lastly, in the absence of a consensus on a generic measurement instrument for place brands, aspects of other African country place brands may be measured by the novel evaluative instrument developed for this study as it was found to be valid and reliable within the South African context. Generally, the evaluative framework developed for the present study to measure the influence of African place brands may 
also be extended to the evaluation of the influence of place brands on other tourism typologies, such as medical, nature-based and leisure tourism in Africa, representing a new vein of critical research in African tourism.

\section{REFERENCES}

Agapito, D., Valle, P.O. \& Mendes, J.C. (2013). The cognitive-affective-conative model of destination image: A confirmatory analysis. Journal of Travel and Tourism Marketing, 30(5): p. 471-481.

Alvarez, M. D. \& Campo, S. (2019). Consumer animosity and its influence on visiting decisions of US citizens. Current Issues in Tourism, https://www.tandfonline.com/action/showCitFormats? doi=10.108o/ 13683500.2019.1603205 (18.04.2019).

Anholt, S. (2002). Nation branding, Journal of Brand Management, 9 (4/5): p. 229 - 239.

Anholt, S. (2007) Competitive identity: The new brand management for nations, cities and regions, Palgrave Macmillan, Basingstoke.

Apostolopoulou, A. \& Papadimitriou, D. (2015). The role of destination personality in predicting tourist behaviour: Implications for branding mid-sized urban destinations. Current Issues in Tourism, 18(12): p. 1132-1151.

Avraham, E. (2018). Nation branding and marketing strategies for combatting tourism crises and stereotypes toward destinations. Journal of Business Research, https://doi.org/10.1016/j.jbusres.2018.02.036 (18.04.2019).

Belloso, J. C. (2010). Country brand. A differentiation mechanism and source of intangibles. Paradigms, 5: p. 44-51.

Bento, J.P.C. (2014). The determinants of international academic tourism demands in Europe. Tourism Economics, 20(3): p. 611-628.

Brijs, K., Bloemer, J. \& Kasper, H. (2011). Country image decisions model: Unravelling meaning, structure, and function of country images. Journal of Business Research, 64: p. 1259-1269.

Chiang, C.C., King, B. E. \& Nguyen, T. H. (2012). Information searching and the travel behaviours of MICE travellers: A cross-cultural study. International Journal of Tourism Research, 14: p. 103-115.

Chikanda, A. \& Tawodzera, G., (2017). Informal entrepreneurship and cross-border trade between Zimbabwe and South Africa, Southern African Migration Programme Migration Policy Series No. 74, Cape Town.

Cook, P. S. (2010). Constructs and experiences of authenticity in medical tourism: The performances of places, spaces, practices, objects and bodies. Tourist Studies, 10(2): p. 135-153.

Das, G. \& Mukherjee, S. (2016). A measure of medical tourism destination brand equity. International Journal of Pharmaceutical and Health Marketing, 10(1): p. 104-128.

Dinnie, K. 2008. Nation branding: Concepts, issues, practice. Burlington, MA: Elsevier

Donaldson, R. (2013). Conference tourism: What do we know about the business tourist in South Africa? African Journal of Physical, Health Education, Recreation and Dance, 2(2013): p. 24-38.

Elliot, S. \& Papadopoulos, N. (2016). Of products and tourism destinations: An integrative, cross-national study of place image. Journal of Business Research, 69: p. 1157-1165.

Field, A. (2011). Discovering statistics using SPSS, $3^{\text {rd }}$ edition. Sage Publications: Los Angeles.

Gisore, R. \& Ogutu, H. (2015). Sustainable tourism in Africa: Standards as essential catalysts. Sector Standardisation Needs Review, 9(3): p. 1-26.

Gowreesunkar, V.G.B. \& Sotiridis, M. (2015). Entertainment of leisure tourists in island destinations: Evidence from the island of Mauritius. African Journal of Hospitality, Tourism and Leisure, 4(Special edition): p. 1-19.

Hair, J.F., Black, W.C., Babin, J.B., Anderson, R.E. \& Tatham, R.L. (2006). Multivariate data analysis. $6^{\text {th }}$ edition. Upper Saddle River: Pearson Prentice Hall.

Han, D. M. (1989). Country image: Halo or summary construct? Journal of Marketing Research, 26(2): p. 222-229.

Hemmonsbey, J. \& Knott, B. (2016). Branding an African city through sport: The role of stakeholder engagement. African Journal of Hospitality, Tourism and Leisure, 5(3): p. 1-15.

Ho, G. \& McKercher, B. (2014). A comparison of long-haul and short-haul business tourists of Hong-Kong. Asia Pacific Journal of Tourism Research, 19(3): p. 342-355.

Hoogendoorn, G. \& Rogerson, C.M. (2016). New perspectives on Southern African tourism research. Tourism, 64(4): p. 355-357.

Kemp, E., Childers C.Y. \& Williams, K.H. (2012). Place branding: Creating self-brand connections and brand advocacy. Journal of Product \& Brand Management, 21(7): p. 508-515.

Khairi, N.D., Ismail, H.N. \& Jaafar, S. M. R. S. (2019). Tourist behaviour through consumption in Melaka World Heritage Site. Current Issues in Tourism, 22(5): p. 582-610.

Kim, S.S., McKercher, B. \& Lee, H. (2009). Tracking tourism destination image perception. Annals of Tourism Research, 36(4): p. 715-718.

Kiryluk, H. \& Glinska, E. (2015). Creation and evaluation of the tourist image of a country: The example of Poland. Procedia - Social and Behavioural Sciences 213(2015): p. 671-676. 
Knott, B., Fyall, A. \& Jones, I. (2013). The nation branding legacy of the 2010 FIFA World Cup for South Africa. Journal of Hospitality Marketing and Management, 22: p. 569-595.

Kumar, J. \& Hussain, K. (2014). A review of assessing the economic impact of business tourism: Issues and approaches. International Journal of Hospitality and Tourism Systems, 7(2): p. 49-55.

Kumar, J., Garg, A. \& Fukey, L.N. (2018). In-depth review of microeconomic analysis of business tourist spending. African Journal of Physical, Health Education, Recreation and Dance, 7(2): p. 39-50.

Marais, M., du Plessis, E. \& Saayman, M. (2017). Critical success factors of a business tourism destination: Supply side analysis. Acta Commercii, 17(1), DOI: 10.4102/ac.v/7/l.423 (18.04.2019).

Martinez, S.C. \& Alvarez, M. D. (2010). Country versus destination image in a developing country. Journal of Travel and Tourism Marketing, 27(7): p. 748-764.

Martin-Santana, J. D., Beerli-Palacio, A. \& Nazzareno, P.A. (2017). Antecedents and consequences of destination image gap. Annals of Tourism Research, 62: p. 13-25.

Matiza, T. \& Oni, O. A. (2014). Managing the tourist destination image: The case of Africa. Tourism, 62(4): p. 397-406.

McCreary, A., Seekamp, E., Davenport, M. \& Smith, J. W. (2019). Exploring qualitative applications of social media data for place-brand assessments in destination planning. Current Issues in Tourism, DOI: $10.1080 / 13683500.2019 .1571023$ (18.04.2019).

Njeru, G.W. (2010). The influence of nation branding on competitiveness of nations. Unpublished $\mathrm{PhD}$ in Business Administration, University of Nairobi, Nairobi.

Norris, M. \& Lecavalier, L. J. (2010). Evaluating the use of exploratory factor analysis in developmental disability psychological research. Journal of Autism and Developmental Disorders, 40(1): p. 8-20.

Nunnally, J. C. \& Bernstein, I. H. (1994). Psychometric theory, $3^{\text {rd }}$ edition. New York: McGraw-Hill.

Park, H. J. \& Lee, T. J. (2017). Influence of the 'slow city' brand association on the behavioural intention of potential tourists. Current Issues in Tourism, 22(12): p. 1405-1422.

Pike, S. (2016). Destination image: identifying baseline perceptions of Brazil, Argentina and Chile in the nascent Australian long-haul travel market. Journal of Destination Marketing and Management, 5: p. 164-170.

Qu, H., Kim, L. H. \& Im, H. H. (2011). A model of destination branding: Integrating the concepts of the branding and destination image. Tourism Management, 32: p. 54-70.

Reitsamer, B. F. \& Brunner-Sperdin, A. 2017. Tourist destination perception and well-being: What makes a destination attractive? Journal of Vacation Marketing, 23(1): p. 55-72.

Rodriguez, V.A., Martinez-Roget, F. \& Pawlowska, E. (2013). Academic tourism: A more sustainable tourism. Regional and Sectorial Economic Studies, 13(2): p. 89-98.

Rogerson, C. M. (2015). The uneven geography of business tourism in South Africa. South African Geographical Journal, 97(2): p. 183-202.

Rogerson, C.M. (2018). Informal sector city tourism: Cross-border shoppers in Johannesburg. GeoJournal of Tourism and Geosites, 22(2): p. 381-392.

Schorr, V. (2011). Economics of Afro-pessimism: The economics of perception in African foreign direct investment, Nokoko Institute of African Studies, Carleton University.

Signé, L. (2018). Africa's tourism potential. Trends, drivers, opportunities, and strategies. Brookings Institution: New York.

Slabbert, E. \& Martin, S. (2017). Aspects influencing the cognitive, affective and conative images of an arts festival. African Journal of Hospitality, Tourism and Leisure, 6(2): p. 1-16.

Souiden, N., Ladhari, R. \& Chiadmi, N. E (2017). Destination personality and destination image. Journal of Hospitality and Tourism Management, 32: p. 54-70.

Stepchenkova, S., Su. L. \& Shichkova, E. (2019). Marketing to tourists from unfriendly countries: Should we even try? Journal of Travel Research, 58(2): p. 266-282.

Steyn, R. \& van Vuuren, O.J. 2016. The relationship between quality of governance and foreign tourist numbers. African Journal of Hospitality, Tourism and Leisure, 5(4): p. 1-10.

Tichaawa, T. (2017). Business tourism in Africa: The case of Cameroon. Tourism Review International, 21 (2): p. 181-192.

Wang, C.L., Li, D., Barns, B. R. \& Ahn, J. (2012). Country image, product image and consumer purchase intentions: Evidence from an emerging economy. International Business Review, 21: p. 1041-1051.

Zenker, S, \& Braun, E. (2010). Branding a city: A conceptual approach for place branding and place brand management, In Proceedings of the $39^{\text {th }}$ European Marketing Academy Conference, Copenhagen: Denmark, 1 June to 4 June 2010.

Zeugner-Roth, K.P and Zabkar, V. (2015). Bridging the gap between country and destination image: Assessing common facets and their predictive validity. Journal of Business Research, 68(2015): p. 1844-1853.

Žugić, J. \& Konatar, A. (2018). Comparative analysis of the value of nation brands. Econviews, 31: p. 179-191. ***** World Travel and Tourism Council. (2018a). Economic impact 2018: World. World Travel and Tourism Council: London.

*** World Travel and Tourism Council. (2018b). Travel and tourism economic impact 2018: South Africa. World Travel and Tourism Council: London.

Submitted:

07.11.2019
Revised:

03.02.2020
Accepted and published online 06.02.2020 